(0.751-0.928). The presence of a US fibrotic TS had an AUC of 0.561 (0.480$0.643)$; with $\mathrm{Se}=0.139(0.094-0.199)$ and $\mathrm{spe}=0.983(0.909-0.997)$. The US-SSc pattern had a AUC of 0.641 (0.563-0.695), with Se=0.440 (0.367$0.516)$ and spe $=0.845(0.731-0.916)$. When used as a diagnostic tool, the original 2013 classification criteria had an AUC of $0.982(0.969-0.996)$ with $\mathrm{Se}=$ $0.946(0.900-0.971)$ and spe $=0.931$ (0.836-0.973). Including UAO and fibrotic TS in this classification had few impact (AUC of $0.979(0.962-0.996)$ with $\mathrm{Se}=$ $0.940(0.893-0.967)$ and and spe $=0.931(0.836-0.973))$ but allows the substitution of some items (such as capillaroscopy) by US parameters with similar performances for diagnosis.

Conclusion: The use of hand US parameters may help to refine the diagnostic strategy of SSc and their inclusion in addition with the items of the ACR/EULAR classification could be discussed.

Disclosure of Interests: Marine de Saint Riquier: None declared, Alice Ballerie: None declared, François ROBIN: None declared, Nicolas Belhomme: None declared, Claire Cazalets: None declared, Catherine Droitcourt: None declared, Aleth Perdriger: None declared, Cécile Marie Yelnik: None declared, Eric Hachulla Speakers bureau: speaking fees from Actelion Pharmaceuticals, GlaxoSmithKline, and Bayer outside of the current study, Vincent Sobanski: None declared, Patrick Jégo: None declared, Guillaume Coiffier: None declared, Alain LESCOAT: None declared

DOI: 10.1136/annrheumdis-2020-eular.5621

\section{THU0353 ENDOCAN AND CIRCULATING PROGENITOR CELLS IN SYSTEMIC SCLEROSIS: ASSOCIATION WITH PULMONARY HYPERTENSION}

A. Lo Gullo ${ }^{1}$, D. Sinicropi ${ }^{2}$, M. Cinquegrani ${ }^{2}$, F. Savarino ${ }^{2}$, C. Giuffrida ${ }^{1}$, G. Squadrito', G. Mandraffino' ${ }^{2}{ }^{1}$ I.R.C.C.S. Centro Neurolesi Bonino Pulejo P.O Piemonte, Messina, Italy; ${ }^{2}$ A.O.U. Policlinico "Gaetano Martino", Messina, Italy

Background: Systemic sclerosis (SSc) is characterized by early vascular involvement and by varying degrees of fibrosis in skin, lungs, and other tissues. Vascular manifestations include Raynaud's phenomenon, digital ulcers, and pulmonary hypertension (PAH). The prevalence of PAH is $7.85-13 \%$ in SSc and it is the second most common cause of mortality in SSc. Circulating CD34+ cell number is associated to cardiovascular health status in several chronic conditions, including inflammatory disease. CD34+ cell number was found inconstantly reduced in SSc. Endocan is a proteoglycan expressed by endothelial cells likely interacting with white blood cells, recently suggested as a marker of vascular stress.

Objectives: to evaluate CD34+ cell number and endocan as a markers od cardiovascular involvement in SSc.

Methods: Standard transthoracic echocardiography, Rodnan skin score were performed. Vitamin D levels, CD34+ cell number, markers of inflammation, red blood cells distribution width (RDW) and Endocan plasma levels were also determined.

Results: 37 female SSc patients (11 diffuse/26 limited) and 35 matched healthy controls $(\mathrm{HC})$ were enrolled. CD34+ cell count was lower as compared to controls $(2.3 \pm 0.73$ vs $2.9 \pm 0.6 ; p<0.001)$, CRP and ESR were significantly higher in SSc patients than controls. Vitamin D3 was lower in SSc patients with respect to controls ( $18 \pm 4.5$ vs $27.26 \pm 10.98 ; p<0.001$ ), Rodnan skin score was $28.89 \pm 10.24$. Endocan was two times greater than controls and serum endocan levels were higher in patients with diffuse Ssc as compared with limited ones. We found no correlation between Endocan and: Rodnan skin score, ESR, fibrinogen; we found a trend of correlation between Endocan and Vitamin D levels $(r=-0.315)$, RDW ( $r=0.310)$, CRP $(r=0.310)$, but statistical significance was not reached likely due to the small sample size. We found an association of PAPs with Endocan levels $(r h o=0.442, p<0.01)$ and $C D 34+$ count $(-0.349, p<0.05$. A significant correlation was also found between Endocan and CD34+ cell number (rho= $-0.605, \mathrm{p}<0.01$ ).

Conclusion: In our study population, we found a significant correlation between CD34+ cell number and Endocan plasma levels and PAPs; Endocan and CD34+ progenitor cells might be suggested as potential marker of pulmonary arterial hypertension in SSc patients.

References:

[1] Lo Gullo et al. Atherosclerosis 2018

Disclosure of Interests: Alberto Lo Gullo Speakers bureau: bayer, Davide Sinicropi: None declared, Mara Cinquegrani: None declared, Francesca Savarino: None declared, Clemente Giuffrida: None declared, Giovanni Squadrito: None declared, Giuseppe Mandraffino: None declared

DOI: 10.1136/annrheumdis-2020-eular.5532

\section{THU0354 \\ CHARACTERIZATION OF ANTI-MYOSITIS ANTIBODY RELATED MYOPATHIES. DESCRIPTIVE STUDY IN A MULTICENTRIC COHORT.}

S. López Salguero ${ }^{1}$, M. Andres ${ }^{2}$, P. Vela-Casasempere ${ }^{2}$, A. Esteban Rodriguez $^{2}$, M. P. Martínez-Vidal ${ }^{3}$, J. A. Bernal ${ }^{4}$, A. Alvarez de Cienfuegos ${ }^{5}$, F. Sivera ${ }^{6} .{ }^{1}$ Hospital Universitario de Torrevieja, Alicante, Spain; ${ }^{2}$ Hospital General Universitario de Alicante, Alicante, Spain; ${ }^{3}$ Hospital Universitario San Juan de Alicante, Alicante, Spain: ${ }^{4}$ Hospital Marina Baixa, Villajoyosa, Spain; ${ }^{5}$ Hospital Vega Baja, Orihuela, Spain; ${ }^{6}$ Hospital Universitario de Elda, Elda, Spain

Background: Idiopathic inflammatory myopathies (IIM) are a group of rare diseases consisting on immune-mediated muscle damage. About 40 to $60 \%$ show specific-myositis antibodies; aditionally, $20-40 \%$ can show myositis-related (non-specific) antibodies. The profile of antibodies can help to divide patients into subgroups with more homogeneous clinical characteristics and prognosis.

Objectives: This study characterizes patients with IIM with specific or related anti-myositis antibodies, in five hospitals in the Alicante health area.

Methods: This is an observational study, carried out in five hospitals with a reference population of 1.083 .463 people. Patients with positive anti-myositis antibodies between October 2015 and May 2018 were selected from the database of the Clinical Laboratory of the University Hospital of Alicante. We considered the following antiboides: anti-myositis specific antibodies (anti-TIF1y, anti-MDA5, anti-Mi-2, anti-PmScl75, anti-PMScl100, anti-NXP2, anti-SRP), anti-synthetase antibodies (anti-PL7, anti-PL12, anti-Jo1, anti-OJ), myositis-related antibodies (anti-Ro52, anti-Ku). Clinical records were examined, identifying those patients with a diagnosis of IIM acording to their clinician, rheumatologist. Epidemiological and clinical data were obtained.

Results: 291 patients with positive anti-myositis antibodies were identified. Among them, 40 patients had a diagnosis of IIM. Median age was 59.5 (IQR $41.5,70)$ years and $68 \%$ were women. Within the subgroups, the most frequent diagnosis were dermatomyositis $(n=22 ; 55 \%)$ and polimyositis $(n=9 ; 22 \%)$. The most common antibody detected was anti-TIF-y among specific antibodies, and anti-Jo-1 among the anti-synthetase antibodies. The most common extramuscular feature was skin involvement. The presence of interstitial lung disease was reported in about one third of patients, being UIP the most commong pattern. Regarding treatment, the use of steroids was generalized; methotrexate was the most used inmunosupresant agent. Eight patients had a cancer related myopathy.

\begin{tabular}{|c|c|c|c|c|c|}
\hline & $\mathrm{DM}(\mathrm{N}=22)$ & PM $(n=9)$ & DMJ (N=3) & $\begin{array}{l}\text { IMNM } \\
(n=1)\end{array}$ & AS $(n=5)$ \\
\hline $\begin{array}{l}\text { Age, median } \\
\text { (IQR) }\end{array}$ & $65,5(46,76)$ & $57(34,66)$ & $15,7(14,18)$ & $83(-)$ & $61(56,64)$ \\
\hline Female $n(\%)$ & $15(68,2)$ & $6(66,6)$ & $2(66,6)$ & $1(100)$ & $3(60)$ \\
\hline $\begin{array}{l}\text { Muscular feat. } \\
\mathrm{n}(\%)\end{array}$ & $16(77,7)$ & $9(100)$ & $1(33,3)$ & $1(100)$ & $5(100)$ \\
\hline ILD n(\%) & $1(4,5)$ & $3(33,3)$ & 0 & 0 & $5(100)$ \\
\hline Disfagia $n(\%)$ & $3(13,6)$ & $1(11,1)$ & 0 & 0 & 0 \\
\hline Skin feat $n(\%)$ & $17(77,3)$ & 0 & $2(66,6)$ & 0 & $1(20)$ \\
\hline arthritis $\mathrm{n}(\%)$ & $1(4,5)$ & 0 & $2(66,6)$ & 0 & $4(80)$ \\
\hline Raynaud n(\%) & $4(19)$ & $1(11,1)$ & 0 & 0 & $1(20)$ \\
\hline Calcinosis $n(\%)$ & $1(4,5)$ & $1(11,1)$ & $(66,6)$ & 0 & 0 \\
\hline $\begin{array}{l}\text { Puffy hands } \\
\text { n (\%) }\end{array}$ & $2(9)$ & 0 & 0 & 0 & $2(40)$ \\
\hline Sicca synd $n(\%)$ & $3(13,6)$ & $1(11,1)$ & 0 & 0 & 0 \\
\hline Cáncer $n(\%)$ & $7(31,8)$ & $1(11,1)$ & 0 & 0 & 0 \\
\hline $\begin{array}{l}\text { Ck máx(UI/I), } \\
\text { median (IQR) }\end{array}$ & $432(171,706)$ & $809(350,1653)$ & - & - & $665(396,2300)$ \\
\hline
\end{tabular}

Conclusion: This register allows us to characterise patients with inflammatory myositis in our area. It is important to make multicentric and prospective registers in infrequent diseases such as IIM in order to have more detailed and representative information about clinical and socio-demographic characteristic as well as prognostic data from these patients.

References:

[1] Dalakas M. Inflammatory Muscle Diseasees. N Engl J Med 2015;372:1734-47. [2]Lündberg IE, Tjärnlund A, Bottai M, et al. 2017 Ann Rheum Dis2017;76:1955-1964.

[3] Betteridge Z, McHugh N. J. Intern Med, 2016 Jul;280(1):8-23.

[4] Nuño L et al. Reumatol Clin. 2017;13(6):331-337

[5] Lilleker JB, Vencovsky J, Wang G, et al.. Ann Rheum Dis 2018;77:30-39

Disclosure of Interests: None declared

DOI: 10.1136/annrheumdis-2020-eular.6125 